\title{
Genetic basis of penicillin resistance of S. aureus isolated in bovine mastitis
}

\author{
Arzu Funda Bagcigil ${ }^{1,2}$, Suvi Taponen ${ }^{*}$, Joanna Koort ${ }^{3}$, Björn Bengtsson ${ }^{4}$, Anna-Liisa Myllyniemi ${ }^{5}$ and Satu Pyörälä ${ }^{1}$
}

\begin{abstract}
Background: The blaZ gene encoding penicillin resistance can be located either chromosomally or on plasmids. The aim of this study was to investigate the genetic relationships and to determine the location of the blaz gene in S. aureus isolated in bovine mastitis in Finland and Sweden.

Methods: Seventy-eight $\beta$-lactamase positive S. aureus isolates from bovine mastitis (34 from Finland and 44 from Sweden) were included in the study. The localization of blaZ gene was determined by Southern blotting. The blaZ genes of the isolates were sequenced and the sequences were translated to beta-lactamase proteins and further grouped as different protein signatures. The isolates and, as control, 33 Swedish and 36 Finnish beta-lactamase negative isolates were typed with pulsed-field gel electrophoresis (PFGE).

Results: In 26 out of 34 Finnish isolates (76.5\%) and in 25 out of 44 Swedish isolates (56.8\%) the blaZ gene was localized on a plasmid. Six different protein signatures were found. One signature was found only in four Swedish isolates, but all other signatures were found both in Finnish and Swedish isolates. The PFGE results revealed a diversity of $S$. aureus clones. The protein signatures were not clearly associated with certain pulsotypes.

Conclusions: The plasmid location of the blaZ gene was not statistically significantly more common in Finland than in Sweden, and hence does not explain the higher proportion of penicillin-resistant isolates of $\mathrm{S}$. aureus causing bovine mastitis in Finland compared to Sweden.
\end{abstract}

Keywords: Mastitis, blaZ, Staphylococcus aureus, Beta-lactamases, Penicillin-resistance Correspondence

\section{Background}

Staphylococcal mastitis is a main problem of the dairy industry in many countries [1]. For mastitis with penicillin-susceptible $S$. aureus, benzylpenicillin is considered a first-line antibiotic due to its advantages compared with beta-lactamase stable penicillin [2]. Unfortunately, resistance to benzylpenicillin is common among mastitis-causing staphylococci, but varies largely between countries [3]. Low prevalences of penicillinresistant $S$. aureus have been reported in Sweden (3.7 to 7.1\%) and Norway (5.0 to $11.4 \%$ ) [3-6] and in Canada (8.7\%) [7]. High prevalences of penicillin-resistance have been reported for example in Estonia (61.4\%). In England (36 to $46 \%$ ) and in Korea (38.6 to $78.8 \%$ ) [3,8,9]. In a prevalence survey in Finland, $52.1 \%$ of S. aureus isolates were penicillin-resistant [10]. In two other studies

\footnotetext{
* Correspondence: suvi.taponen@helsinki.fi

'Department of Production Animal Medicine, Faculty of Veterinary Medicine, University of Helsinki, Helsinki, Finland

Full list of author information is available at the end of the article
}

the level of resistance was lower, $22.9 \%$ and $25.0 \%$ $[11,12]$. It is, however, peculiar, why penicillin-resistance is clearly more common in Finland than in the neighbouring Nordic countries with similar conditions for milk production. One explanation could be the more common plasmid location of the blaZ gene and plasmid-mediated spread of penicillin-resistance.

Resistance to benzylpenicillin is mainly caused by the blaZ gene encoding production of beta-lactamases, which hydrolytically destroy beta-lactams [13]. The blaZ gene can be located chromosomally or on plasmids [14]. This type of penicillin resistance in $S$. aureus may thus emerge via two mechanisms: spread of resistant clones or through horizontal dissemination of mobile elements containing the blaZ gene $[15,16]$. Location of the resistance determinants on transferable elements generally promotes efficient spread [16]. In Denmark the blaZ gene of penicillin resistant $S$. aureus isolates has been predominately located chromosomally [17]. Diversity of
C Biomed Central 
the blaZ gene cluster can be studied by gene phylogenetic analysis $[18,19]$ and be compared with published bla $Z$ sequences, to find out possible relatedness.

The aim of this study was to investigate the location and diversity of the blaZ gene in S. aureus isolated in bovine mastitis in Finland and Sweden. In addition, the genetic relationships of $S$. aureus isolates were investigated. Our hypothesis was that location of the resistance gene on a plasmid would be associated with a higher prevalence of resistance. In addition, we investigated the diversity of bla $Z$ sequences and compared the amino acid sequences of the beta-lactamase protein according to Olsen et al. [18].

\section{Methods}

\section{Bacterial isolates}

A total of 78 beta-lactamase positive $S$. aureus isolates from bovine mastitis (34 isolates from Finland and 44 isolates from Sweden) from previous surveys were included in the study. Out of the 34 isolates from Finland, 15 were collected in 2001 from subclinical mastitis [10] and 19 were collected in 2005 from clinical mastitis [12]. Out of the 44 Swedish isolates, 18, 12 and 14 isolates were from 2001, 2002/2003 and 2005, respectively. The isolates from 2001 and 2005 were from subclinical/chronic mastitis and were collected from diagnostic submissions to the Swedish National Veterinary Institute. The isolates from 2002/2003 were collected in a specific study on acute clinical mastitis [5].

Sixty-nine beta-lactamase negative isolates from both countries (36 isolates from Finland and 33 isolates from Sweden) were included in the pulsed-field gel electrophoresis (PFGE) analyses for comparison. Fourteen Finnish isolates were from 2001 and 22 from 2005. Out of the 33 Swedish isolates; 18 isolates were from 2001 and 15 from 2002/2003. The 36 Finnish and 33 Swedish beta-lactamase negative isolates originated from the same surveys described above $[5,10,12]$.

The reference strain S. aureus ATCC 29213 was used for both $n u c$ and blaZ PCR assays as a positive control and also for the probe preparation for Southern blotting. A beta-lactamase-producing S. aureus strain SV 41 was used in Southern blotting as the control of plasmid localisation of the blaZ gene [18].

\section{Confirmation of the isolates and PCR detection of the blaZ gene}

Species confirmation was performed using PCR amplification of the thermonuclease $(n u c)$ gene with the primers; P-1: 5' GCG ATT GAT GGT GAT ACG GTT 3'; P-2: $5^{\prime}$ AGC CAA GCC TTG ACG AAC TAA AGC $3^{\prime}$ as described previously [20]. After the confirmation of presence of the nuc gene, all the isolates were further examined for the blaZ gene by using primers (blaZ $1: 5^{\prime}$
TTA AAG TCT TAC CGA AAG CAG $3^{\prime}$; blaZ 2: $5^{\prime}$ TAA GAG ATT TGC CTA TGC TT- $3^{\prime}$ ) designed by Olsen et al. [18]. The PCR-amplified products were separated by electrophoresis in a $1.5 \%$ agarose gel in $\mathrm{lx}$ TBE buffer (pH 8.3; $0.09 \mathrm{M}$ Tris, $0.09 \mathrm{M}$ boric acid, $2.0 \mathrm{mM}$ EDTA) and stained with ethidium bromide $(0.5 \mathrm{ug} / \mathrm{ml}$ final concentration), visualized in UV-light and image analysed on AlphaImager HP Digital Imaging System, Model DE-500 (Alpha Innotech Corporation, San Leandro, CA, USA).

\section{Location of the blaZ gene in penicillin-resistant strains}

The beta-lactamase positive isolates were included in Southern blotting analysis for the detection of the location of the blaZ gene. The bacteria were cultivated in $10 \mathrm{ml}$ of Trypticase soy broth (TSB), supplemented with $10 \%$ yeast extract and benzylpenicillin at a final concentration of $8 \mu \mathrm{g} / \mathrm{ml}[17]$.

\section{Purification and digestion of chromosomal DNA and plasmid DNA}

DNA was purified using the Easy-DNA ${ }^{\mathrm{ma}}$ Kit for genomic DNA isolation (Invitrogen Life Technologies, Carlsbad, CA, USA) according to the manual. For lysis of bacterial cells, $10 \mu \mathrm{l}$ of lysostaphin $(10 \mathrm{mg} / \mathrm{mL})$ and $7,5 \mu \mathrm{l}$ of lysozyme $(20 \mathrm{mg} / \mathrm{mL})$ were added and the suspensions incubated at $37^{\circ} \mathrm{C}$ for $45 \mathrm{~min}$. The E.Z.N.A. ${ }^{\mathrm{mx}}$ Plasmid Miniprep Kit (Omega Bio-Tek. Inc., GA, USA) was used for the purification of plasmid DNA. Purified chromosomal and plasmid DNA were digested with one unit of EcoRI (Roche Diagnostic, Mannheim, Germany) and EcoRV (Roche Diagnostic) for $2 \mathrm{~h}$ and run on a $0.8 \%$ Tris-borate EDTA agarose gel. A Digoxigenin (DIG)labelled DNA Molecular Weight Marker II (Roche Diagnostic) served to determine the size of the digested chromosomal fragments [18].

\section{Southern blotting}

A probe (377 bp) for the blaZ gene was prepared by PCR amplification on the S. aureus ATCC 29213 using the primers P1 and P2. Probe DNA was purified using Easy DNA Kit (Invitrogen, K1800-01) and labelled with digoxigenin-11-dUTP using DIG PCR Probe Synthesis Kit (Roche Diagnostic). DNA bands from chromosomal and plasmid digests were transferred from agarose gels onto Nylon membranes (Roche Diagnostic) by capillary transfer following depurination in $250 \mathrm{mM} \mathrm{HCl}$, denaturation in $0.5 \mathrm{M} \mathrm{NaOH}, 1.5 \mathrm{M} \mathrm{NaCl}$ and neutralization in $0.5 \mathrm{M}$ Tris- $\mathrm{HCl}, 1.5 \mathrm{M} \mathrm{NaCl}$ steps, as previously described [21]. Blots were prehybridised for $2 \mathrm{~h}$ at $42^{\circ} \mathrm{C}$ in prehybridisation solution (DIG Easy Hyb; Roche Applied Science). Denatured probe was added and hybridised to membranes for $12 \mathrm{~h}$ at $42^{\circ} \mathrm{C}$ in a hybridization oven. Membranes were then washed twice 
for $5 \mathrm{~min}$ at room temperature in $2 \times$ Saline Sodium Citrate (SSC) buffer containing $0.1 \%$ Sodium Dodecyl Sulfate (SDS), and then twice for $15 \mathrm{~min}$ at $65^{\circ} \mathrm{C}$ in $0.5 \times$ SSC-0.1\% SDS. Chromogenic detection method was used for the visualization of the probes on the blot.

\section{PFGE analysis}

Both beta-lactamase positive and negative isolates (totally 147 isolates) were examined by PFGE as previously described by Salmenlinna et al. [22]. Briefly, S. aureus colonies from overnight cultures were incorporated into low melting agarose (2\%) plugs. The DNA purification protocol included lysostaphin and proteinase $\mathrm{K}$ treatment, followed by washing steps with phenylmethylsulfonyl fluoride and TE buffer $(10 \mathrm{mM}$ Tris and $1 \mathrm{mM}$ EDTA, pH 8.0). Genomic DNA was digested using SmaI at room temperature, overnight. PFGE was performed by clamped homogeneous electric field (CHEF) electrophoresis with a CHEF-DR III System (Bio-Rad Laboratories, CA, USA) in a $1 \%(\mathrm{w} / \mathrm{v})$ SeaKem agarose gel (FMC BioProducts, USA) at $6 \mathrm{~V} / \mathrm{cm}$ by two phases: phase 1 for $10 \mathrm{~h}$, with the initial and final switching times of $5 \mathrm{~s}$ to $15 \mathrm{~s}$; and phase 2 for $13 \mathrm{~h}$, with $15 \mathrm{~s}$ to 60 s, respectively. A Lambda Ladder PFG marker (New England BioLabs, USA) was used as the molecular weight standard. Fragments ranging from 50 to $800 \mathrm{~kb}$ were included in the analysis. Gels were analysed using BioNumerics v. 4.61 software (Applied Maths, Kortrijk, Belgium), and cluster analysis was performed by Unweighted Pair Group Method with Arithmetic Mean (UPGMA) based on the Dice similarity coefficient, with optimization and position tolerance set at $1.5 \%$. Fingerprints with more than three band shifts were interpreted as being of a different pulsotype and thus the strains genetically unrelated.

\section{Sequencing of the blaZ gene}

The blaZ genes of the beta-lactamase positive isolates were sequenced in the Institute of Biotechnology, Helsinki. The primers used for sequencing of plasmid located blaZ were 486: GTTGCGAACTCTTGAATAGG and 531: AATTCCTTCATTACACTCTTGG [18]. The primers used for sequencing of chromosomally located blaZ were 1 F: TACAACTGTAATATCGGAGGG and 1R: CATTACACTCTTGGCGGTTTC [19]. The gene sequences were translated to amino acid sequences using Transeq Nucleotide to Protein Conversion (European Bioinformatics Institute). The blaZ nucleotide sequences and the corresponding beta-lactamase amino acid sequences were compared with published sequences, retrieved from the GenBank, using BioNumerics24.61 software (Applied Maths). The amino acid sequences were grouped into protein signatures (three or less deviations in amino acid composition) according to Olsen et al. [18].

\section{Statistical methods}

Frequencies of plasmid versus chromosomal location of bla $Z$ genes in isolates from Sweden and Finland, and in isolates from clinical versus subclinical mastitis were compared using Pearson's chi-square test.

\section{Results}

\section{Confirmation of the isolates}

All 147 isolates included in the study were S. aureus, as they showed amplification products at approximately 270 bp for nuc gene. All the 78 beta-lactamase positive isolates had the bla $\mathrm{Z}$ gene confirmed by showing bands at $377 \mathrm{bp}$.

\section{Location of the blaZ gene in penicillin-resistant strains}

Based on the Southern blotting, the blaZ gene was located on the chromosome in 27 isolates and on plasmids in 51 isolates. In 26 of the 34 beta-lactamase positive Finnish isolates (76\%) and in 25 of the 44 betalactamase positive Swedish isolates (56.8\%), the blaZ gene was located on a plasmid. The difference of the blaZ gene location between the Finnish and Swedish isolates was not statistically significant $(\mathrm{p}=0.094)$.

Of the 27 isolates with chromosomally located blaZ, 12 (44.4\%) were from clinical mastitis and 15 (55.6\%) from subclinical mastitis. Of the 51 isolates with plasmid-located blaZ, 19 (37.3\%) were from clinical and $32(62.7 \%)$ from subclinical mastitis. The location of blaZ did not significantly differ between isolates from different type of mastitis (clinical vs. subclinical) $(\mathrm{p}=0.629)$.

\section{PFGE analysis}

The $147 \mathrm{~S}$. aureus isolates showed 81 different pulsotypes. Twenty-seven, 18 and 16 isolates belonged to three dominating pulsotypes; the other pulsotypes included mainly one or few isolates. The most common pulsotype (28 isolates, 18 Finnish and 10 Swedish) included only beta-lactamase negative isolates. The pulsotype with 18 isolates (3 Finnish, 15 Swedish) included 16 isolates carrying the bla $Z$ gene on a plasmid and two beta-lactamase negative isolates. The pulsotype with 16 isolates (7 Finnish and 9 Swedish) included 15 betalactamase negative isolates and one isolate carrying the bla $Z$ gene on the chromosome. Most of the pulsotypes included few either beta-lactamase positive or negative isolates.

\section{Sequencing of the blaZ gene}

The blaZ gene of 71 isolates (47 plasmid and 24 chromosomally located) of the total of 78 bla $Z$ possessing 
isolates was successfully sequenced. Forty-seven plasmid-located and 6 chromosomally located blaZ regions were successfully amplified and sequenced using the primer pair 486-531. The length of the obtained sequences were $797 \mathrm{bp}$. Amplification of the chromosomally located blaZ regions of 18 isolates failed with these primers but succeeded using the primer pair $1 \mathrm{~F}-1 \mathrm{R}$, and sequences of $833 \mathrm{bp}$ were obtained. In the further analysis, the region from 1 to $797 \mathrm{bp}$ of the total blaZ gene of 846 bp of all 72 isolates was used. When the sequences were translated to proteins, amino acid sequences of 265 amino acids of the total length of 281 amino acids of the beta-lactamase protein were obtained.

Eighteen different amino acid sequences were obtained. Six different protein signatures, the signatures $1,2,3,5,6$, and a new signature $2 / 5$, which had similarities with the signatures 2 and 5 , were found (Table 1). The most common signature type was the signature 3, including 24 plasmid and one chromosome located blaZ. The signature 6 included only chromosomally located blaZ $(\mathrm{n}=17)$ and the signature 2 mainly plasmid located blaZ (15 plasmid, 1 chromosome). The protein signature of 7 isolates, including five chromosomally and two plasmid located blaZ, fell between the protein signatures 2 and 5 , having $>3$ amino acid deviations from both. The protein signature of this group was similar (0 to 1 deviations) to the protein signature of Enterococcus faecalis with GenBank accession number U43087 [23], reported to belong to the protein signature $5[18,19]$, but different ( $>3$ deviations) from the other protein signature 5 references with accession numbers M25257, AY373761, AJ302698, and DQ919081.

The four isolates with the signature type 1 had an almost identical pulsotype, as had also the seven isolates with the signature type $2 / 5$. The 25 isolates with the signature type 3 were divided into two groups of similar pulsotypes. The 16 isolates with the signature type 2 had rather similar pulsotypes but the 17 isolates with the signature type 6 had 11 different pulsotypes (Table 1).

We compared the beta-lactamase protein sequences of our isolates with the sequences submitted to the GenBank having a known beta-lactamase serotype or protein signature. The type B beta-lactamase corresponded to the protein signature 6 , only found from isolates carrying the blaZ gene on the chromosome. The betalactamase type A corresponded to the protein signature 1 , and the beta-lactamase type $\mathrm{D}$ to the protein signature 5 , but representatives of beta-lactamase type $\mathrm{C}$ corresponded both to the protein signatures 2 and 3 .

\section{Discussion}

In most (76\%) of the Finnish S. aureus isolates and in over half $(57 \%)$ of the Swedish isolates blaZ gene was residing on a plasmid. The high proportion of penicillin-resistant $S$. aureus in Finland [10,12] could have been explained by plasmid-mediated resistance. However, nearly half of the Swedish isolates also had the gene on a plasmid but prevalence of penicillin resistant S. aureus has been low in Sweden [5,6]. Possession of the blaZ gene was partly linked to pulsotype, which may indicate a clonal spread of resistance. Under the selection pressure of antibiotic use, resistant populations of bacteria have advantage over susceptible ones and can become dominant. If possession of a resistance gene results in a fitness cost, resistant clones would disappear after cessation of antibiotic use. However, regarding blaZ-positive $S$. aureus, no evidence of a possible fitness cost is available as shown for some Gram-negative bacteria with other beta-lactamase genes [24]. It seems that other factors than location of the blaZ gene explain different prevalence of penicillin resistance among mastitis causing $S$. aureus in Sweden and Finland.

In spite of introduction of large scale mastitis control programs, S. aureus has remained a major mastitis

Table 1 Beta-lactamase protein signatures of the blaZ genes located chromosomally or on a plasmid in S. aureus isolates in bovine mastitis in Finland and Sweden

\begin{tabular}{|c|c|c|c|c|c|c|}
\hline \multirow{2}{*}{$\begin{array}{l}\text { Protein } \\
\text { signature }\end{array}$} & \multicolumn{2}{|c|}{ Finland } & \multicolumn{2}{|c|}{ Sweden } & \multirow[b]{2}{*}{ Total } & \multirow[b]{2}{*}{ Pulsotypes } \\
\hline & Chromosome & Plasmid & Chromosome & Plasmid & & \\
\hline 1 & & & & 4 & 4 & 2 different pulsotypes \\
\hline 2 & 1 & 13 & & 2 & 16 & 8 different pulsotypes \\
\hline 3 & & 10 & 1 & 14 & 25 & Two clusters of $>64 \%$ similarity, with 8 and 4 different pulsotypes \\
\hline 5 & & 1 & & 1 & 2 & 2 pulsotypes with $78 \%$ similarity \\
\hline 6 & 4 & & 13 & & 17 & 9 different pulsotypes \\
\hline $2 / 5$ & 3 & 1 & 2 & 1 & 7 & $\begin{array}{l}\text { A cluster of } 4 \text { pulsotypes with } 81 \% \text { similarity and } 1 \text { pulsotype with } 61 \% \\
\text { similarity within the cluster }\end{array}$ \\
\hline Total & 8 & 25 & 16 & 22 & 71 & \\
\hline
\end{tabular}

Fingerprints of the pulsed field gel electrophoresis (PFGE) with more than three band shifts were interpreted as being of a different pulsotype and thus the strains genetically unrelated. 
pathogen in many countries $[4,10]$. S. aureus infection can persist for long periods in the mammary gland and needs to be treated with antimicrobials [25]. In human medicine, benzylpenicillin has lost its value as a therapeutic agent for treatment of $S$. aureus infections, because almost $100 \%$ of the isolates have been resistant for decades [26]. In isolates of human origin, the blaZ gene has been reported to be located predominantly on a plasmid [26]. For treatment of bovine staphylococcal mastitis, benzylpenicillin can still be regarded as a firstline antibiotic [2,27].

Many countries regularly monitor resistance of animal pathogens, including $S$. aureus isolates in bovine mastitis, by national monitoring programs. Based on the reports of these programs and other investigations, penicillin resistance of $S$. aureus is the most common form of antimicrobial resistance among mastitis causing bacteria $[3,8]$. In Finland, a nation-wide survey carried out in 2001 showed that the proportion of penicillinresistant S. aureus isolates was $52 \%$ in subclinical mastitis [10]. In a more recent study on isolates from clinical mastitis, the proportion of resistance was only 25\% [12]. The decreasing trend in penicillin-resistance of $S$. aureus could be due to mastitis control measures such as culling of cows infected with resistant isolates, but also due to the more prudent use of antibiotics [28]. However, the data are not fully comparable as the first originate from subclinical and the more recent from clinical mastitis. The differences in prevalence of penicillin-resistant $S$. aureus isolated in mastitis observed between countries may be explained by different management options to control S. aureus mastitis but possibly also by different use patterns of antimicrobials for mastitis treatment [15]. In Norway and Sweden, use of antimicrobials has been very restricted and benzylpenicillin has practically been the only antimicrobial used to treat mastitis over decades $[27,29]$. This indirect evidence may indicate that use of benzylpenicillin does not efficiently select for penicillin-resistance among mastitis causing $S$. aureus. Yet, systemic administration of penicillin or intramammary administration of dry cow penicillin-novobiocin combination were associated with penicillin resistance in Canadian dairy herds [7]. Similar results were reported also by Pol and Ruegg [30]. Together with restricted antimicrobial policy, strict culling of cows with mastitis caused by penicillin-resistant $S$. aureus has been advised for long in Sweden and in Norway. In Finland a wider selection of intramammary products containing broadspectrum antimicrobials and combinations of different substances were earlier used [31]. In most countries, consumption figures of antimicrobials for different animal species are not available or not detailed enough, and no conclusions can be made on the associations between antimicrobial use and resistance.
The beta-lactamases of $S$. aureus have been classified immunologically by the serotype into four classes, types A-D [26]. The gene variant encoding the type B betalactamase is located on the chromosome whereas the gene variants encoding the types $\mathrm{A}, \mathrm{C}$, and $\mathrm{D}$ betalactamases are usually located on a plasmid [26]. These four beta-lactamase types correspond with the blaZ protein sequence signatures established by Olsen et al. [18], who reported 11 protein signature types for the blaZ sequences from staphylococci of different origin. Malik et al. [19] used the same protein signature classification and detected four known protein signature types and one new type from isolates from dogs and cats. We found five of these protein signatures, the signatures 1 , $2,3,5$ and 6 , and a new signature, which had similarities both with the signatures 2 and 5 and was named 2/5. The majority of our isolates with the blaZ gene in the chromosome were of the protein signature type 6, which clustered with the beta-lactamase protein sequences from the GenBank having the beta-lactamase serotype B. The protein signature 6 was detected only in isolates with chromosomal location of the bla $Z$ gene. This is in concordance with earlier studies [26]. The new protein signature type 2/5 was found in seven isolates (4 Finnish and 3 Swedish), of which five carried the blaZ gene on the chromosome. The pulsotypes of these isolates were very similar, indicating clonal spread. The protein signature 1 corresponded with the beta-lactamase type A, and the protein signature 5 with the beta-lactamase type D. The protein signatures 2 and 3 corresponded with the beta-lactamase type $\mathrm{C}$. With two exceptions, the protein signatures 1, 2, 3 and 5 were found in plasmid located blaZ,which is in agreement with other studies $[18,26]$.

Certain genotypes of mastitis causing $S$. aureus can become dominant in the dairy herds [25]. In the three most common pulsotypes here blaZ-negative isolates were over-represented, indicating that penicillinresistance was partly related to pulsotype. An association between certain pulsotypes and penicillin susceptibility has also been shown previously [32,33]. Penicillinresistance may be linked to other virulence factors of $S$. aureus, which may facilitate the spread of resistant clones [33]. Intramammary infection remained significantly more often chronic if it was caused by blaZ positive $(61.0 \%$ remained persistent) than blaZ negative (25.0\%) strains [34]. In Denmark, penicillin resistance in mastitis causing $S$. aureus in 1950s was exclusively found in isolates of the same phagetype and ribotype, but found among several clones in 1992 [35]. The authors suggested that penicillin-resistance was introduced to bovine Staphylococcus population first by one clone but then became widespread among several clones, probably due to horizontal transfer. According to a Norwegian study, 99 of 107 penicillin and tetracycline resistant 
S. aureus isolates in 18 herds belonged to the same clone [36]. Location of the resistance genes was not determined but the resistance was suggested to have spread through a single clone and a resistance plasmid.

\section{Conclusions}

Presence of the blaZ gene of $S$. aureus was pulsotypelinked. Six different protein signatures were found and all except one both in Finnish and Swedish isolates. The protein signatures were not clearly associated with certain pulsotypes. The bla $Z$ gene was located on plasmids in more than half of the isolates. The plasmid location of the blaZ gene was not statistically significantly more common in Finland than in Sweden, and hence does not explain the higher penicillin-resistance in $S$. aureus causing bovine mastitis in Finland compared to Sweden.

\section{Competing interests}

The authors declare that they have no competing interests.

\section{Authors' contributions}

AFB performed the laboratory analyses and drafted the manuscript.

ST helped in laboratory and statistical analyses and drafted the manuscript and performed the analysis of sequences. SP designed and coordinated the study and drafted the manuscript. BB and A-LM participated in study design and helped to draft the manuscript. All authors read and approved the final manuscript.

\section{Acknowledgements}

CIMO organization and Walter Ehrström Foundation are acknowledged for supporting this work financially.

\section{Author details}

${ }^{1}$ Department of Production Animal Medicine, Faculty of Veterinary Medicine, University of Helsinki, Helsinki, Finland. '2Department of Microbiology, Faculty of Veterinary Medicine, University of Istanbul, Istanbul, Turkey. ${ }^{3}$ Department of Basic Veterinary Sciences, Faculty of Veterinary Medicine, University of Helsinki, Helsinki, Finland. ${ }^{4}$ National Veterinary Institute, SE-751 89, Uppsala, Sweden. ${ }^{5}$ Finnish Food Safety Authority Evira, Helsinki, Finland.

Received: 7 September 2012 Accepted: 19 November 2012 Published: 23 November 2012

\section{References}

1. Barkema H, Schukken YH, Zadoks RN: Invited review: the role of cow, pathogen, and treatment regimen in the therapeutic success of bovine staphylococcus aureus mastitis. J Dairy Sci 2006, 89:1877-1895.

2. Constable P, Pyörälä S, Smith G: Guide for antimicrobial use in cattle. In Antimicrobial Use in Animals. Edited by Guardabassi L, Jensen LB, Kruse H. Singapore: Blackwell Publishing Ltd, Fabulous Printers PTE Ltd; 2008:143-160

3. Hendriksen RS, Mevius DJ, Schroeter A, Teale C, Meunier D, Butaye P, Franco A, Utinane A, Amado A, Moreno M, Greko C, Stärk K, Berghold C, Myllyniemi A-L, Wasyl D, Sunde M, Aarestrup FM: Prevalence of antimicrobial resistance among bacterial pathogens isolated from cattle in different European countries: 2002-2004. Acta Vet Scand 2008, 50:28.

4. Østerås O, Sølverød L, Reksen O: Milk culture results in a large Norwegian survey - effects of season, parity, days in milk, resistance and clustering. J Dairy Sci 2006, 89:1010-1023.

5. Bengtsson B, Unnerstad HE, Ekman T, Artursson K, Nilsson-Ost M, Waller KP: Antimicrobial susceptibility of udder pathogens from cases of acute clinical mastitis in dairy cows. Vet Microbiol 2009, 136:142-149.

6. Persson Y, Nyman A-KJ, Grönlund-Andersson U: Etiology and antimicrobial susceptibility of udder pathogens from cases of subclinical mastitis in dairy cows in Sweden. Acta Vet Scand 2011, 53:36.
7. Saini V, McClure JT, Scholl DT, DeVries TJ, Barkema HW: Herd-level association between antimicrobial use and antimicrobial resistance in bovine mastitis staphylococcus aureus isolates on Canadian dairy farms. J Dairy Sci 2012, 95:1921-1929.

8. Kalmus P, Aasmäe B, Kärssin A, Orro T, Kask K: Udder pathogens and their resistance to antimicrobial agents in dairy cows in Estonia. Acta Vet Scand 2011, 53:4.

9. Nam H-M, Lee A-L, Jung M-NK, Jang G-C, Wee S-H, Lim S-K: Antimicrobial susceptibility of staphylococus aureus and characterization of methicillin-resistant staphylococcus aureus isolates from bovine mastitis in Korea. Foodborne Pathog Dis 2011, 8:231-238.

10. Pitkälä A, Haveri M, Pyörälä S, Myllys V, Honkanen-Buzalski T: Bovine mastitis in Finland - prevalence, distribution of bacteria, and antimicrobial resistance. J Dairy Sci 2004, 87:2433-2441.

11. Nevala M, Taponen S, Pyörälä S: Bacterial etiology of bovine clinical mastitis - data from saari ambulatory clinic in 2002-2003. Suomen Eläinlääkärilehti (Finnish Vet J) 2004, 110:363-369.

12. FinRes-Vet 2005-2006: Finnish veterinary antimicrobial resistance monitoring and consumption of antimicrobial agents. www.evira.fi/uploads/ WebShopFiles/1198141211941.pdf.

13. Pinho MG: Mechanisms of $\beta$-lactam and glycopeptides resistance in Staphylococcus aureus. In Staphylococcus molecular genetics. Edited by Lindsay JA. Norwich, Norfolk, UK: Caister Academic Press; 2008:207-226.

14. Lyon BR, Skurray RA: Antimicrobial resistance of staphylococcus aureus: genetic basis. Microbiol Rev 1987, 51:88-134.

15. Aarestrup FM, Schwarz S: Antimicrobial resistance in staphylococci and streptococci of animal origin. In Antimicrobial resistance in bacteria of animal origin. Edited by Aarestrup FM. Washington, DC: ASM Press; 2006:187-212.

16. Malachowa N, DeLeo FR: Mobile genetic elements of Staphylococcus aureus. Cell Mol Life Sci 2010, 67:3057-3071.

17. Vesterholm-Nielsen $M, \varnothing \mid$ hom Larsen M, Olsen JE, Aarestrup FM: Occurrence of the blaZ gene in penicillin resistant Staphylococcus aureus isolated from bovine mastitis in Denmark. Acta Vet Scand 1999, 40:279-286.

18. Olsen JE, Christensen H, Aarestrup FM: Diversity and evolution of blaZ from Staphylococcus aureus and coagulase-negative staphylococci. J Antimicrob Chemother 2006, 57:450-460.

19. Malik S, Christensen H, Peng H, Barton MD: Presence and diversity of the $\beta$-lactamase gene in cat and dog staphylococci. Vet Microbiol 2007, 123:162-168.

20. Brakstad OG, Aasbakk K, Maeland JA: Detection of Staphylococcus aureus by polymerase chain reaction amplification of the nuc gene. $J$ Clin Microbiol 1992, 30:1654-1660.

21. Sambrook J, Fritsch EF, Maniatis T: Molecular cloning. A laborafory manual. 2nd edition. Cold Spring Harbor, New York: Cold Spring Harbor Laboratory Press; 1989.

22. Salmenlinna S, Lyytikäinen O, Kotilainen P, Scotford R, Siren E, Vuopio-Varkila J: Molecular epidemiology of methicillin-resistant Staphylococcus aureus in Finland. Eur J Clin Microbiol Infect Dis 2000, 19:101-107.

23. Tomayko JF, Zscheck KK, Singh KV, Murray BE: Comparison of the beta-lactamase gene cluster in clonally distinct strains of Enterococcus faecalis. Antimicrob Agents Chemother 1996, 40:1170-1174.

24. Marciano DC, Karkouti OY, Palzkill T: A fitness cost associated with the antibiotic resistance enzyme SME-1 beta-lactamase. Genetics 2007, 176:2381-2392.

25. Anderson $\mathrm{KL}$, Lyman RL: Long-term persistence of specific genetic types of mastitis causing Staphylococcus aureus on three dairies. J Dairy Sci 2006, 89:4551-4556.

26. Livermore DM: $\beta$-lactamases in laboratory and clinical resistance. Clin Microbiol Reviews 1995, 8:557-584.

27. NMSM (Nordiske Meieriorganisasjoners Samarbeidsutvalg for Mjolkekvalitetsarbeid): Nordiska riktlinjer för mastitbehandling (Nordic guidelines for mastitis treatment), Meeting of the Nordic Dairy Association's Committee for Milk Quality, 12th June 2009, Lund, Sweden; 2009. http://www.sva.se/upload/Redesign2011/Pdf/antibiotika/ Nordiska_riktlinjer_for_mastitbehandling_lagupplost.pdf.

28. Pyörälä S, Kaartinen L, Simojoki H, Kivilahti-Mäntylä K: Use of intramammary antimicrobials in Finland - towards lower consumption and targeted treatment of mastitis. Lisbon, Portugal: XXVII World Buiatrics Congress; 2012:85. Abstracts, OC 14 
29. Grave T, Greko C, Nilsson L, Odensvik K, Mørk T, Rønning M: The usage of veterinary antibacterial drugs for mastitis in cattle in Norway and Sweden during 1990-1997. Prev Vet Med 1999, 42:45-55.

30. Pol M, Ruegg PL: Relationship between antimicrobial drug usage and antimicrobial susceptibility of gram-positive mastitis pathogens. J Dairy Sci 2007, 90:262-273.

31. FinRes-Vet 1999: Bacterial Resistance to Antimicrobial Agents in Finland. http://wwwb.mmm.fi/el/julk/finres99en.html.

32. Haveri M, Taponen S, Vuopio-Varkila J, Salmenlinna S, Pyörälä S: Bacterial genotype affects the manifestation and persistence of bovine Staphylococcus aureus intramammary infection. J Clin Microbiol 2005, 43:959-961.

33. van den Borne BHP, Nielen M, van Schaik G, Melchior MB, Lam TJGM, Zadoks RN: Host adaptation of bovine Staphylococcus aureus seems associated with bacteriological cure after lactational antimicrobial treatment. J Dairy Sci 2010, 93:2550-2558.

34. Taponen S, Jantunen A, Pyörälä E, Pyörälä S: Efficacy of targeted 5-day combined parenteral and intramammary treatment of clinical mastitis caused by penicillin-susceptible or penicillin-resistant Staphylococcus aureus. Acta Vet Scand 2003, 44:53-62.

35. Vintov J, Aarestrup FM, Zinn CE, Olsen JE: Phage types and antimicrobial resistance among Danish bovine Staphylococcus aureus isolates since the 1950s. Vet Microbiol 2003, 97:63-72.

36. Waage S, Bjorland J, Caugant DA, Oppegaard H, Tollersrud T, Mørk T, Aarestrup FM: Spread of Staphylococcus aureus resistant to penicillin and tetracycline within and between dairy herds. Epidemiol Infect 2002, 129:193-202.

doi:10.1186/1751-0147-54-69

Cite this article as: Bagcigil et al:: Genetic basis of penicillin resistance of S. aureus isolated in bovine mastitis. Acta Veterinaria Scandinavica 2012 54:69.

\section{Submit your next manuscript to BioMed Central and take full advantage of:}

- Convenient online submission

- Thorough peer review

- No space constraints or color figure charges

- Immediate publication on acceptance

- Inclusion in PubMed, CAS, Scopus and Google Scholar

- Research which is freely available for redistribution 